\title{
Piotr Köhler
}

Institute of Botany, Faculty of Biology

Jagiellonian University, Kraków, Poland

ORCID 0000-0001-8713-0817

\section{The First Flora of Poland}

A flora is a publication containing a list of species of wild plants of a given region along with the information on their localities, descriptions of their morphology, and keys for their determination. Johannes Thal's Sylva Hercynia is considered the first flora ever published. From the $18^{\text {th }}$ century onwards, floras of entire Western European countries were being published. Opisanie roslin $w$ prowincyi $W$. X. L. naturalnie rosnących według układu Linneusza (Description of plants in the province of the $G$ [rand] $D$ [uchy of] $L$ [ithuania] naturally growing according to the Linnaeus system) by Stanisław Bonifacy Jundziłł was printed in 1791. It includes 1,297 species, comprising 1,052 flowering plants, 85 mosses, 64 fungi, 49 lichens, 34 ferns and 13 algae, and contains 97 localities from the then Polish part of the Polish-Lithuanian Commonwealth and 198 from the then Lithuanian one. The species are arranged according to the Linnaeus system, and their descriptions are concise. Contrary to its title, Opisanie roslin covers both the territories of Lithuania and Poland, which is why it should also be considered the earliest modern flora of Poland. Opisanie roslin played an important role in the history of Polish botany, especially in the development of floristics in Poland and Lithuania in the early $19^{\text {th }}$ century.

Keywords: history of botany, floristics, Poland

Słowa kluczowe: historia botaniki, florystyka, Polska

The term 'flora' has two meanings in botany. It may relate to 1. all species of plants growing in a given region (e.g. flora of the Tatra Mountains), and 2. a publication containing a list of these species together with the information on their exact localities, descriptions of their morphological features, and keys for identification; such a work also includes information on the history of floristic studies of a given area and takes into account the results of these studies, providing quotes of these results, with appropriate comments if necessary. This study refers to the latter meaning.

The turbulent history of Poland in the $17^{\text {th }}$ and $18^{\text {th }}$ centuries affected the poor development of Polish science, including botany, during that period. ${ }^{1}$ In the $18^{\text {th }}$ century,

1 Z. Kosiek, Botanika, [in:] Zarys dziejów nauk przyrodniczych w Polsce, ed. by K. Maślankiewicz, Warszawa 1983, p. 422-424; Historia nauki polskiej, vol. 2, ed. by S. Suchodolski, Wrocław - Warszawa - Kraków 1970, p. 128-131; B. Hryniewiecki, Rozwój botaniki w Polsce, Kraków 1948 (PAU Historia Nauki Polskiej w Monografiach, vol. 8), p. 6-7; A. Zemanek, Zarys historii botaniki w Polsce, [in:] Dzieje nauki. Nauki ścisłe i przyrodnicze, ed. by R. W. Gryglewski et al., Warszawa - Bielsko-Biała 2011, p. 453. 
when the floras of other countries were published, the Polish-Lithuanian Commonwealth experienced a political collapse, which ended in the loss of independence in 1795. In each of the three parts of the former state, under the rule of Austria, Prussia, and Russia respectively, their floras were published in the $19^{\text {th }}$ century. ${ }^{2}$ Only after Poland had regained its independence in 1918, the so-called single-volumed 'small flora of Poland' was released in 1924. ${ }^{3}$ The publishing of a multi-volume flora started in 1919 and was not completed until $1995 .{ }^{4}$ But the question remains: was the flora of 1924 by Szafer, Kulczyński and Pawłowski truly the first flora of Poland?

\section{An outline of the history of European floras until the end of the $18^{\text {th }}$ century}

Sylva Hercynia by Johannes Thal (1542-1583), a physician in Stolberg, at the foot of the Harz Mountains, may be considered the first flora in the second of the above meanings. ${ }^{5}$ Although this flora was created as early as 1577 , it was not published until 1588 after the author's death. Earlier works on plants of a given region contained only selected species, primarily useful plants, especially cultivated ones and those of medical importance. In contrast, Sylva Hercynia lists only wild plants. ${ }^{6}$ The term 'flora' in the latter sense was used for the first time in the title of Flora Sinensis (Viennae 1656), a work by Michał Boym (1612-1659), a 17 ${ }^{\text {th }}$-century Polish missionary in China. ${ }^{7}$

Extensive research on European plants during the $17^{\text {th }}$ century, conducted mainly in the university cities, resulted in the creation and subsequent publication of numerous local floras. Mägdefrau, in his History of Botany, gives some examples: Ludwig Jungermann (1572-1653) wrote a flora of Altdorf (1615), and then Giessen (1623); Elias Tillandz (16401693) - a flora of Åbo in Finland (1673); John Ray (1627-1705) - a flora of Cambridge (1660); Joseph Pitton de Tournefort (1656-1708) - a flora of Paris (1698), which was soon followed by another, written by his student Sébastien Vaillant (1669-1722) in 1723. In

2 Kingdom of Galicia and Lodomeria (Austrian part) - W.S.J.G. Besser, Primitiae florae Galiciae austriacae utriusque. Encheiridion ad excursiones botanicas cincinnatium, vol. 1-2, Viennae 1809; Congress Poland (Russian part) - J. Waga, Flora Polska jawno kwiatowych rodzajów czyli Botaniczne opisy tak dzikich jako i hodowanych pod otwartém niebem jawno kwiatowych Królestwa Polskiego Roślin, vol. 1-2, Warszawa 1847-1848; Grand Duchy of Posen (Prussian part) - J.B. Motty, Leitfaden der Botanik, Posen 1830; G. Ritschl, Flora des Grossherzogthums Posen, Berlin 1850.

3 W. Szafer, S. Kulczyński, B. Pawłowski, Rośliny polskie. Opisy i klucze do oznaczania wszystkich gatunków roślin naczyniowych rosnących w Polsce bądź dziko, bądź też zdziczałych lub częściej hodowanych, Lwów-Warszawa 1924.

4 Flora polska. Rośliny naczyniowe Polski i ziem ościennych, vol. 1, ed. by M. Raciborski, W. Szafer, Kraków 1919; vol. 2, ed. by W. Szafer, Kraków 1921; vol. 3, ed. by W. Szafer, Kraków 1927; vol. 4, ed. by W. Szafer, Kraków 1930; vol. 5, ed. by W. Szafer, Kraków 1935; vol. 6, ed. by W. Szafer, Kraków 1947; vol. 7, ed. by W. Szafer, B. Pawłowski, Kraków - Warszawa 1955; vol. 8, ed. by W. Szafer, B. Pawłowski, Warszawa 1959; vol. 9, ed. by W. Szafer, B. Pawłowski, Kraków 1960; vol. 10, ed. by B. Pawłowski, Warszawa - Kraków 1963; vol. 11, ed. by B. Pawłowski, Warszawa - Kraków 1967; vol. 12, ed. by B. Pawłowski, A. Jasiewicz, Warszawa - Kraków 1971; vol. 13, ed. by B. Pawłowski, A. Jasiewicz, Warszawa - Kraków 1972; vol. 14, ed. by A. Jasiewicz, Warszawa Kraków 1980; vol. 15, ed. by Z. Mirek, Kraków 1995.

5 J. Thal, Sylva Hercynia, Sive Catalogus Plantarum Sponte Nascentium In Montibus, Et Locis Vicinis Hercyniae, quae respicit Saxoniam, conscriptus singulari studio, Francofurti ad Moenum 1588.

6 K. Mägdefrau, Historia botaniki. Życie $i$ dokonania wielkich badaczy, transl. by M. Mularczyk, Wrocław 2004 (Prace Ogrodu Botanicznego Uniwersytetu Wrocławskiego, vol. 7, no. 1), p. 44.

7 M. Boym, Flora sinensis, fructus floresque humillime, Viennae 1656. 
1718, Heinrich Bernhard Rupp (1688-1719) published a flora of Jena, and Johann Jakob Dillenius (1684-1749) - a flora of Giessen. ${ }^{8}$

The degree of botanical research of entire countries increased so much during the $17^{\text {th }}$ century that their floras began to be released in the following century. One of the first publications of this type was a flora of Prussia (1703) by Johannes Loesel (1607-1655), ${ }^{9}$ and a flora of Switzerland of 1710 by Johannes von Muralt (1645-1733). ${ }^{10}$ Carl Linnaeus (1707-1778) produced a flora of Sweden in 1745. ${ }^{11}$ A four-volume flora of Siberia was published between 1747 and 1769 by Johann Georg Gmelin (1709-1755). ${ }^{12}$ From 1761 until 1883, Flora Danica was published as a botanical atlas, the first author of which was the German-Danish botanist Georg Christian Edler von Oldenburg Oeder (1728-1791). ${ }^{13}$ In 1773, Nikolaus Joseph von Jacquin (1727-1817) produced a flora of Austria ${ }^{14}$ and, four years later, Jean Baptiste de Lamarck (1744-1829) - a flora of France. ${ }^{15}$

\section{An outline of the history of Polish floras until the mid- $18^{\text {th }}$ century}

The history of works describing plant species growing in various cities or regions of Poland is unexpectedly long. The first publication containing floral data comes from the Renaissance. In 1557, Anton Schneeberger (1530-1581), a Swiss physician and naturalist associated with the court of King Sigismund II Augustus in Kraków, published Catalogus stirpium - an alphabetical list of 270 species of wild plants and 162 cultivated ones around Kraków. ${ }^{16}$ It was in fact the first publication about the city's flora. Around 1580, the evangelical bishop Johannes Wigand (1523-1587) residing in Liebemühl (now: Miłomłyn) in Pomerania made quite extensive records regarding the flora of the region, mainly around the city of Osterode (now: Ostróda). After the bishop's death, his botanical notes were included in the publication Vera historia de succino Borussico. ${ }^{17}$ The author of the second publication on the flora of the Kraków area, titled Plantarum Cracoviensium, was Gabriel Joannicy (1565-1613), a professor at the University of Kraków. ${ }^{18}$ Unfortunately, the work is no longer extant. The first flora of Gdańsk Pomerania, Elenchus plantarum, was written by Nicolaus Ölhafen (1604-1643), and it includes about 350 species of wild

8 K. Mägdefrau, op. cit., p. 61-62.

9 J. Loesel, Flora Prussica, sive Plantae in Regno Prussiae sponte nascentes, Königsberg 1703.

10 J. Muralt, Physicae specialis, pars quarta, botanologia, seu Helvetiae Paradisus, Tiguri 1710.

11 C. Linnaeus, Flora Svecica Exhibens plantas per Regnum Sveciae Crescentes, Lugduni Batavorum 1745.

12 J.G. Gmelin, Flora Sibirica, sive Historia plantarum Sibiriae, vol. 1-4, Petropoli 1747-1769.

13 G.C. Edler von Oldenburg Oeder et al., Enumeratio plantarum florae Danicae, id est sponte nascentium in regnis Daniae et Norvegiae, ducatibus Slesvici et Holsatiae, comitatibus Oldenburgi et Delmenhorstiae, vol. 1-51, Hafniae 1761-1883.

14 N.J. Jacquin, Florae Austriacae, sive, Plantarum selectarum in Austriae archiducatu sponte crescentium icones, ad vivum coloratae, et descriptionibus, ac synonymis illustratae, vol. 1-5, Viennae 1773-1778.

15 J.B. Lamarck, Flore françoise, ou, Description succincte de toutes les plantes qui croissent naturellement en France disposée selon une nouvelle méthode d'analyse, \& à laquelle on a joint la citation de leurs vertus les moins équivoques en médecine, \& de leur utilité dans les arts, vol. 1-3, Paris 1778.

16 A. Schneeberger, Catalogus stirpium quarundam Latinè et Polonicè conscriptus, Cracoviae 1557.

17 J. Wigand, Vera historia de succino Borussico, de alce Borussia et de herbis in Borussia nascentibus, Jenae 1590.

18 G. Joannicy, Plantarum Cracoviensium indicem proprium Latine confectum, Cracoviae 1616. 
plants. ${ }^{19} \mathrm{~A}$ description of each of them contains information about the place of occurrence (locality), time of flowering, and use in medicine.

Catalogus plantarum tum exoticarum comes from the mid- $17^{\text {th }}$ century ${ }^{20}$ and was written by Martin Bernhardi (ca. 1625-before 1682), a physician and librarian of King John II Casimir Vasa. The work consists of three catalogues of plants; two of them relate to the royal gardens in Warsaw, and the third one - to the vicinity of Warsaw. In total, this work lists about 700 plant species. The second flora of the surroundings of this city was published in 1730; it is titled Viridarium vel Catalogus plantarum circa Varsaviam nascentium, and contains about 900 species - including mushrooms - growing wild near Warsaw. The Viridarium was attached to the description of the city: Warsavia Physice Illustrata. ${ }^{21}$ It was written by Christian Heinrich Erndtel (1676-1734), court physician of King Augustus II the Strong. In 1764, Gottfried Reyger (1704-1788), a member of the Gdańsk Society for Life Sciences, published a two-volume flora of Gdańsk: Tentamen florae Gedanensis methodo sexuali adcommodatae, in which he used the Linnaeus system as one of the first in the world. ${ }^{22}$ The flora of Grodno was issued in 1781-1782 by the Frenchman Jean Emmanuel Gilibert (1741-1814). ${ }^{23}$ From the above review, it can be seen that these floras covered small areas - around towns or, at most, a province. Prior to the 1790s, there was no work which would cover the area of the entire Commonwealth, or at least Poland.

\section{Stanisław Bonifacy Jundziłł and his flora}

In 1791, Stanisław Bonifacy Jundziłł published a book titled Opisanie roslin (Description of plants). The treatise is a focus of this study. Jundziłł received his initial education at Piarist schools in Lida (now in Belarus), Szczuczyn (now: Shchuchyn in Belarus) and Lubieszów (now: Lubeshiv in Ukraine). In 1779, he joined the Piarist order. At Vilnius University (then called the Vilnius Principal School), he studied mainly philosophy and theology between 1781-1785, and zoology between 1786-1787. He also attended private botany courses of Johann Georg Forster (1754-1794) who was then a professor of natural history at the university. In 1779-1786, Jundziłł worked as a teacher in various Piarist schools, spending the longest time in Vilnius, Polish-Lithuanian Commonwealth (Vilna; then and in Polish: Wilno). He then completed his education during two sojourns abroad. The first one took place between 1792 and 1794 in Vienna (where he studied botany, mineralogy, and chemistry) and in Freiberg, Saxony (where he studied mineralogy and became acquainted with the mining and metallurgy industries). During the second visit, in 1795-1797, he studied, among others, zoology, animal physiology, and pharmacy at the Veterinary School in Vienna. In the years 1792-1824, he worked at the University

19 N. Ölhafen, Elenchus plantarum, circa nobile Borussorum Dantiscum, sua sponte nascentium, [Dantisci] 1643.

20 M. Bernhardi, Catalogus plantarum tum exoticarum quam indigenarum quae Anno MDCLI in hortis regiis Varsaviae et circa eandem in locis sylvaticis, pratensibus, arenosis et paludosis nascuntur collectarum, Dantisci 1652.

21 C.H. Erndtel, Warsavia Physice Illustrata, Sive De Aere, Aquis, Locis Et Incolis Warsaviae, Eorundemque Moribus Et Morbis Tractatus; Cui Annexum Est Viridarium, Vel Catalogus Plantarum Circa Warsaviam Nascentium, Dresdae 1730.

22 G. Reyger, Tentamen florae Gedanensis methodo sexuali adcommodatae, vol. 1-2, Dantisci 1764-1766.

23 J.E. Gilibert, Flora lituanica inchoata, seu enumeratio plantarum quas circa Grodnam collegit et determinavit, vol. 1-2, Vilnae 1781-1782. 
of Vilnius (between 1797-1803, the university was called the Vilnius Principal School, and after 1803 - the Imperial University of Vilnius): between 1792-1802 as a vice-professor of natural history, 1802-1803 - a full professor of natural history, and in the years 18031824 - a full professor of botany. He also managed the university botanical garden. In 1798, he obtained a doctorate in philosophy at the Vilnius Principal School based on a dissertation in mineralogy, and in 1800 a doctorate in theology. He published at least 26 botanical papers and several textbooks on botany and zoology. ${ }^{24}$

In 1791 in Vilnius, Jundziłł published a flora in Polish. Its full original title reads: Opisanie roslin w prowincyi W. X. L. naturalnie rosnących według układu Linneusza przez x. B.S. Jundziłła S.P. $w$ Wilnie 1791, which can be rendered in English as: Description of plants in the province of the $G$ [rand] $D$ [uchy of] $L$ [ithuania] naturally growing according to the Linnaeus system by the Rev. Bonifacy Stanisław Jundzitł Scholarum Piarum in Vilnius 1791. ${ }^{25}$ The abbreviation 'W. X. L.' in the title means 'Wielkie Xięstwo Litewskie' (Grand Duchy of Lithuania) in the $18^{\text {th }}$-century Polish spelling. For unknown reasons, Jundziłł used the abbreviation instead of the full name of only one of the parts of the then PolishLithuanian Commonwealth. The Opisanie roslin was produced in 'the printing house of His Royal Majesty and the Commonwealth at the Piarist Fathers'. The title pages of the preserved copies reveal two graphic variants - one more decorative, and the other less. The first has a woodcut frame and a large typographic ornament with a floral motif, whereas 'Mci' (an abbreviation of 'Mości', meaning 'Majesty') was left in the name of the printing house. The latter has no frame, and the typographic ornament with a floral motif is much smaller and less ornate (Fig. 1).

The flora consists of several parts: introduction (p. 1-61), Carl Linnaeus's biography (p. 62-76), description of the Linnaeus system (p. 77-83), keys to genera and descriptions of species (p. 84-571), a register of Polish generic names (7 unnumbered pages), and a register of Latin generic names (7 unnumbered pages). Even before the introduction, there is a list of 174 people who subscribed to this flora (in the copies with a less decorative title page, the list contains one more person), and most of them came from the Grand Duchy of Lithuania. In the extensive introduction, Jundziłł contained pieces of information on the history of general (p. 4-13) and Polish botany (p. 39-50), and also on plant morphology with elements of plant physiology (p. 14-35), while data on practical applications of the plants occupy only a few pages (p. 36-39 and 56-61).

In the introduction, Jundziłł also presents a genesis of his flora. During 11 years preceding the work's publication, he collected plants, taking advantage of the fact that he was working then in various places in the Grand Duchy of Lithuania. He boasts that he managed to collect almost as many species as Gilibert did, however he admits that he did not find all the species described by him. This is a fair point. At the end of the 18th century, botanists (including Gilibert) were still unaware of sometimes huge

24 The most extensive biography: W. Sławiński, X. Stanisław Bonifacy Jundziłt profesor Historii Naturalnej Wszechnicy Wileńskiej. The Rev. Stanisław Bonifacy Jundzitf Professor of Natural History in the University of Wilno, „Annales Universitatis Mariae Curie-Skłodowska Lublin - Polonia” sectio E vol. 1, 1947, Supplementum I. See also: P. Köhler, Leksykon Botaników Polskich. Dictionary of Polish Botanists. 80. Stanisław Bonifacy Jundziłt, „Wiadomości Botaniczne” vol. 55, 2011, no. 1/2, p. 94-98.

25 S. B. Jundziłł, Opisanie roslin w prowincyi W. X. L. naturalnie rosnących według układu Linneusza przez $x$. B.S. Jundzitła S.P. $w$ Wilnie 1791, Wilno 1791. 

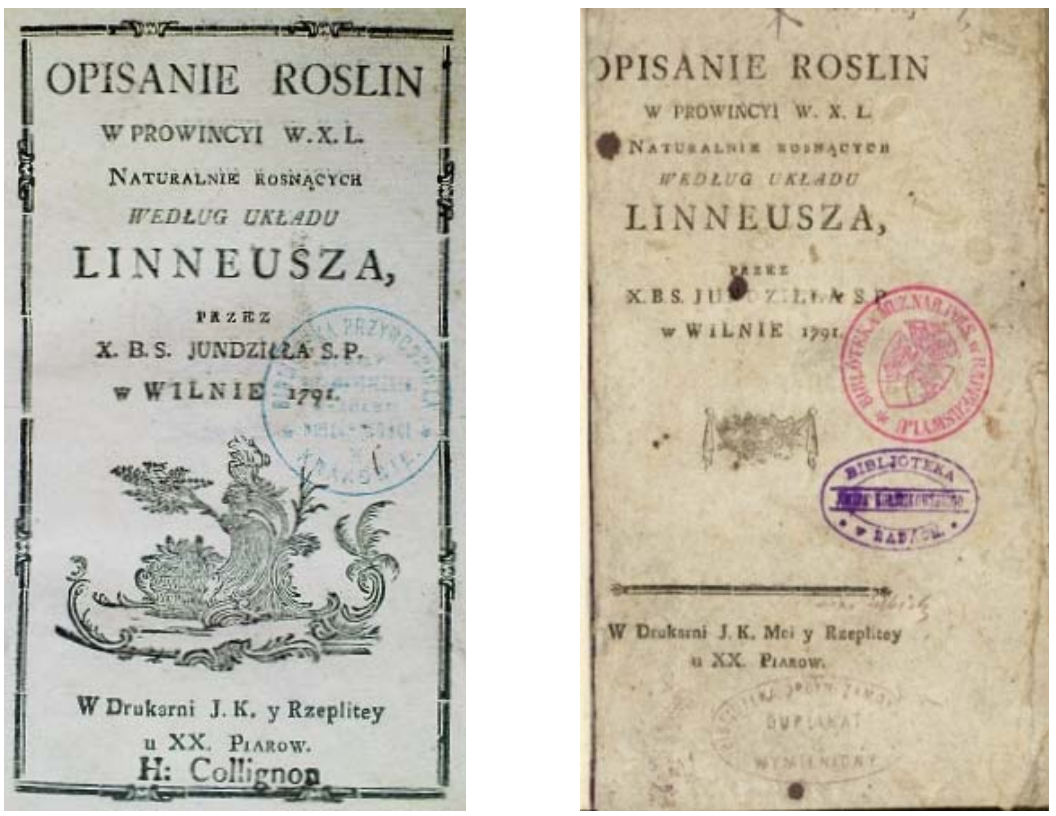

Fig. 1. Opisanie roslin by Jundziłł - two typographic versions of the title page

differences in the species composition (i.e. flora) in various areas. Gilibert, using foreign floras for determining Lithuanian species, made many mistakes resulting from the floristic dissimilarities between Lithuania and Western European countries. ${ }^{26}$ Jundziłł trusted Gilibert uncritically enough that he quoted Gilibert's species without omitting the doubtful ones ('I must confess, however, that many Grodno plants, despite the most careful search, could not have been found [by me], and I give descriptions of these [species] after Gilibert'). ${ }^{27}$ Therefore, he included in his flora, after Flora Lithuanica inchoata by Gilibert, also species that did not grow in the Grodno region, e.g. Phyteuma orbiculare L. (it grows only in southern Poland), Euphorbia dendroides L. (it grows in the Mediterranean, ranging from the Iberian Peninsula to Egypt), or Cirsium eriophorum (L.) Scop. (in Poland, it grows almost exclusively in the Carpathians). The second work from which Jundziłł took floristic data was Dykcyonarz roślinny (Dictionary of plants) by Jan Krzysztof Kluk (1739-1796). ${ }^{28}$

The main part of Opisanie roslin is the systematic part containing keys for the identification of genera and descriptions of the genera and species of flowering plants, bryophytes, fungi, lichens, ferns, and algae - a total of 1,297 species (Table 1).

26 P. Köhler, Naukowa spuścizna Jeana Emmanuela Giliberta w Polsce (egzemplarze dziet, recepcja), "Kwartalnik Historii Nauki i Techniki" vol. 60, 2015, no. 1, p. 191.

27 S.B. Jundziłł, Opisanie roslin w prowincyi W. X. L., p. 50-51.

28 K. Kluk, Dykcyonarz roślinny, w którym podług układu Linneusza są opisane rośliny nietylko kraiowe dzikie, pożyteczne, albo szkodliwe, na roli, w ogrodach, oranzeriach, utrzymywane, ale oraz y cudzoziemskie, ktoreby w kraiu pożyteczne byc mogły, albo z ktorych mamy lekarstwa, korzenie, farby, etc. albo ktore jakową nadzwyczaynosc w sobie maia, ich zdatnosci lekarskie, ekonomiczne, dla ludzi, koni, bydła, owiec, pszczot, i t.d. utrzymywanie etc. Z poprzedzaiącym wykładem słow Botanicznych, y kilkorakim na końcu Regestrem, vol. 1-3, Warszawa 1788-1788. 
Table 1. Opisanie roslin by S.B. Jundziłł - systematic content

\begin{tabular}{|l|c|}
\hline Group of organisms & Number of species (in parentheses - number of localities) \\
\hline flowering plants & $1,052(280)$ \\
\hline bryophytes & $85(1)$ \\
\hline fungi & $64(0)$ \\
\hline lichens & $49(3)$ \\
\hline ferns and ferns allies & $34(11)$ \\
\hline algae & $13(0)$ \\
\hline Total: & $1,297(295)$ \\
\hline
\end{tabular}

While preparing his flora, Jundziłł must have used earlier studies. Most of them concerned slightly different areas than he would like to embrace with his flora. They were, among others, the then published parts of the already mentioned Flora Danica, ${ }^{29}$ Florae Austriacae (5 volumes, 1773-1778) by Nikolaus von Jacquin, ${ }^{30}$ Fungorum qui in Bavaria et Palatinatu circa Ratisbonam nascuntur icones (atlas of colourful engravings) by Jacob Christian Schaeffer (1718-1790), ${ }^{31}$ and the first two parts of Beschreibung der Gräser (1769-1779) by Johann Christian Daniel von Schreber (1739-1810).32 Jundziłł also used two already mentioned works concerning some areas of the Polish-Lithuanian Commonwealth: Dykcyjonarz roślinny by Kluk, ${ }^{33}$ and Flora Lithuanica inchoata by Gilibert. ${ }^{34}$

In addition to the descriptions of species, Jundziłł sometimes provides information about their occurrence in different places. Opisanie roslin contains such kind of data in the case of 295 species (Table 2). Jundziłł gave 166 localities based on his own research, 85 quotes after Kluk, and 52 - after Gilibert. In total, he gives 303 localities (for some species more than 1) - 97 from the then Poland and 198 from the then Grand Duchy of Lithuania.

The main features of Opisanie roslin by Jundziłł indicate that it is a modern flora:

1. System - taxa, mainly genera, are arranged according to the Linnaeus system. For comparison: in Kluk's Dykcyonarz roślinny, the arrangement is alphabetical by Latin genera names.

2. Descriptions of individual taxa - concise, in the form of diagnosis (they contain characteristics of a given taxon that allow for distinguishing it from others), contain information about habitat and sometimes on occurrence. Other information, including practical applications - sporadic and laconic. For comparison: in Kluk's Dykcyonarz roślinny, the descriptions of genera still have a large amount of information beyond systematic, e.g. about the practical uses of a species.

3. The area covered by this flora - contrary to its title, Opisanie roslin by Jundziłt covers both the Grand Duchy of Lithuania and Poland.

29 G.C. Edler von Oldenburg Oeder et al., op. cit.

30 N.J. Jacquin, op. cit.

31 J.C. Schaeffer, Fungorum qui in Bavaria et Palatinatu circa Ratisbonam nascuntur icones, nativis coloribus expressae, vol. 1-4, Ratisbonae 1762-1774.

32 J.C.D.E. von Schreber, Beschreibung der Gräser nebst ihren Abbildungen nach der Natur, vol. 1-2, Leipzig 1769-1772.

33 K. Kluk, op. cit.

34 J.E. Gilibert, op. cit. 
Table 2. Opisanie roslin by S.B. Jundziłł - localities.

\begin{tabular}{|l|l|l|c|}
\hline \multicolumn{1}{|c|}{ Locality } & Province & \multicolumn{1}{|c|}{$\begin{array}{c}\text { Source } \\
\text { of data }\end{array}$} & $\begin{array}{c}\text { Number } \\
\text { of } \\
\text { species }\end{array}$ \\
\hline Vilnius and its surroundings & Lithuania & Jundziłł's own data & 91 \\
\hline Podlasie & Poland & J.K. Kluk & 87 \\
\hline $\begin{array}{l}\text { Grodno (now: Hrodna, Belarus) } \\
\text { and its surroundings }\end{array}$ & Lithuania & J.E. Gilibert & 66 \\
\hline Lida (now in Belarus) & Lithuania & Jundziłł's own data & 20 \\
\hline Szczuczyn (now: Shchuchyn, Belarus) & Lithuania & Jundziłł's own data & 6 \\
\hline Brześć nad Bugiem (now: Brest, Belarus) & Lithuania & J.E. Gilibert & 5 \\
\hline Warszawa & Poland & J.E. Gilibert & 4 \\
\hline Dukszty (now: Dūkštas, Lithuania) & Lithuania & Jundziłł's own data & 3 \\
\hline Ciechanowiec & Poland & J.K. Kluk & 2 \\
\hline Białystok & Poland & J.E. Gilibert & 1 \\
\hline $\begin{array}{l}\text { Niemen i Szczara (now: Nioman and } \\
\text { Shchara Rivers, Belarus) }\end{array}$ & Lithuania & Jundziłł's own data & 1 \\
\hline Dzitwa (now: Dzitva River, Belarus) & Lithuania & Jundziłł's own data & 1 \\
\hline Jaszuny (now: Jašiūnai, Lithuania) & Lithuania & Jundziłł's own data & 1 \\
\hline Krynki & Poland & J.E. Gilibert & 1 \\
\hline Lublin & Poland & J.K. Kluk & 1 \\
\hline Baltic Sea coast & Poland & J.E. Gilibert & 1 \\
\hline Podole (now: Podilla, Ukraine) & Poland & Jundziłł's own data & 1 \\
\hline $\begin{array}{l}\text { Polesie (now: Palesse, Belarus and Polissa, } \\
\text { Ukraine) }\end{array}$ & Lithuania & Jundziłł's own data & 1 \\
\hline $\begin{array}{l}\text { Puszcza Rzeczycka i na pruskiej granicy } \\
\text { (the unclear name of a place and a forest } \\
\text { on the Prussian border) }\end{array}$ & Lithuania & Jundziłł's own data & 1 \\
\hline Wierciliszki (now: Vercalishki, Belarus) & Lithuania & J.E. Gilibert & 1 \\
\hline
\end{tabular}

The features described above indicate that the Opisanie roslin by Jundziłł is a typical modern flora, even if the exact term is not included in the title. Due to the geographical scope, which also included Poland's localities, it is also the flora of Poland. And since none of the earlier floras covered more extensive areas of Poland, Opisanie roslin by Jundziłł should also be considered the earliest modern flora of Poland.

\section{The role of Opisanie roslin in the development of botany in Poland}

Opisanie roslin by Jundziłł played a significant role in the history of Polish botany, and it was quickly appreciated. As early as 1792, King Stanisław II August Poniatowski awarded Jundziłł with the gold Merentibus Medal for this publication. By writing his Opisanie roslin in Polish and using an easy-to-use key based on the Linnaeus system, Jundziłt probably wanted to provide a manual for determining plants, which was lacking in the Polish language at the time. This easy key would allow students interested in botany, as well as pharmacists, to quickly determine plants. In fact, from the beginning of the $19^{\text {th }}$ century, 
there was an increase in interest in botany among Vilnius University students, ${ }^{35}$ so perhaps Jundziłł's book could have contributed to this. Its popularity can also be indirectly testified by the fact that Opisanie roslin was a publication that was difficult to buy in a relatively short time after its release. ${ }^{36}$

Opisanie roslin was not intended to settle any taxonomic issues since Jundziłł was not a skillful plant taxonomist. Despite this fact, his work later gained recognition even among professional taxonomists, as evidenced by the citations in such studies as a flora of the Soviet Union ${ }^{37}$ or a flora of Lithuania. ${ }^{38}$ Regrettably, Flora polska - the primary Polish study - does not contain a list of publications. The author is sure that if it did, Opisanie roslin would have been included there. ${ }^{39}$

Almost immediately after finishing his Opisanie roslin, Jundziłł began working on the supplement. As he informs in the introduction, the reason for this was that while collecting data for his work, he also found many plants whose characteristics did not match the descriptions of species in the floras he had. ${ }^{40}$ Moreover, he also envisaged further research in the areas yet unexplored where he expected to find new species. Unfortunately, the announced supplement never appeared. However, twenty years later, in 1811, Jundziłł published the second edition of Opisanie roslin under a slightly changed title: Opisanie roslin litewskich według układu Linneusza (Description of Lithuanian plants according to the Linnaeus system).$^{41}$ This edition was thoroughly redone, especially in terms of Polish taxa names.

Both editions were important stages in the formation of Polish names of plant genera and species. The evolution of these names was critically analyzed by Rostafiński. ${ }^{42}$ According to him, Kluk very often used two words instead of one in generic names (i.e. in the first part of a binominal name - nomen triviale). Jundziłt replaced all these two-word generic names (72 in total) in Opisanie roslin with single words. He did the same with the second part of a binominal name, i.e. nomen specificum. Unfortunately, he also changed further 88 one-word generic names to new ones. In Opisanie roslin litewskich, he changed 28 one-word names of Kluk and 33 generic names he had previously created himself in Opisanie roslin. Thus, Jundziłł rebelled against the taxonomy rules formulated at the beginning of the $18^{\text {th }}$ century by John Ray regarding the botanical nomenclature. The first of these rules prohibits changing already existing names in order to avoid confusion and mistakes..$^{43}$ Therefore, one should not be surprised by Rostafiński's critical opinion about

35 W. Grębecka, Badania szaty roślinnej prowadzone w ośrodku wileńskim i krzemienieckim (1781-1840), [in:] Wkład wileńskiego ośrodka naukowego w przyrodnicze poznanie kraju (1781-1842), ed. by J. Babicz, W. Grębecka, Wrocław - Gdańsk 1988 (Monografie z Dziejów Nauki i Techniki, vol. 141), p. 163-179; W. Grębecka, Wilno-Krzemieniec. Botaniczna szkoła naukowa (1781-1841), Warszawa 1998 (Rozprawy z Dziejów Nauki i Techniki, vol. 7).

36 A. Andrzejowski, Flora Ukrainy czyli opisanie roślin dziko rosnących w Ukrainie Przeddnieprowej i w sąsiednich z nią okolicach Wołynia, Podola i Guberni Chersońskiej, Warszawa 1869, p. XII.

37 Flora SSSR, ed. by V. L. Komarov, vol. 4, Leningrad 1935, p. 480

38 Lietuvos TSR Flora, vol. 6, V. Galinis et al., Vilnius 1980, p. 335.

39 Flora polska.

40 S.B. Jundziłł, Opisanie roslin w prowincyi W. X. L., p. 51-52.

41 Idem, Opisanie roslin litewskich według układu Linneusza, Wilno 1811.

42 J. Rostafiński, Słownik polskich imion rodzajów oraz wyższych skupień roślin poprzedzony historyczną rozprawą o źródłach, Kraków 1900 (Materyały do Historyi Języka i Dyalektologii Polskiej, vol. 1), p. 20-23.

43 J. Ray, Methodus plantarum emendata et aucta. In quâ notae maxime characteristicae exhibentur, quibus stirpium genera tum summa, tum infima cognoscuntur \& à se mutuo dignoscuntur, non necessariis omissis. Accedit methodus graminum, juncorum et cyperorum specialis, Londini 1703, cit. Regulae I. 
these unnecessary name changes made by Jundziłł. Only the Polish names of species and genera included in Opisanie roslin litewskich became the basis for Polish scientific plant names. ${ }^{44}$

\section{Final remarks}

As shown above, Opisanie roslin by Jundziłł is the first modern flora of Poland (and also of Lithuania) which marks the beginning of modern Polish floristics and modern Polish plant taxonomy. This work also proves the rebirth of Polish science (in this case: botany) after a period of stagnation. In addition, Opisanie roslin is chronologically the second flora in Poland (after Tentamen florae Gedanensis by Reyger ${ }^{45}$ ) to use the Linnaeus system. It played a significant role in the development of plant research in Poland and Lithuania at the turn of the $19^{\text {th }}$ century.

\section{Bibliography}

\section{Sources}

Andrzejowski A., Flora Ukrainy czyli opisanie roślin dziko rosnących $w$ Ukrainie Przeddnieprowej i w sąsiednich z nią okolicach Wołynia, Podola i Guberni Chersońskiej, Warszawa 1869.

Bernhardi M., Catalogus plantarum tum exoticarum quam indigenarum quae Anno MDCLI in hortis regiis Varsaviae et circa eandem in locis sylvaticis, pratensibus, arenosis et paludosis nascuntur collectarum, Dantisci 1652.

Besser W.S.J.G., Primitiae florae Galiciae austriacae utriusque. Encheiridion ad excursiones botanicas cincinnatium, vol. 1-2, Viennae 1809.

Boym M., Flora sinensis, fructus floresque humillime, Viennae 1656.

Edler G.C. von Oldenburg Oeder et al., Enumeratio plantarum florae Danicae, id est sponte nascentium in regnis Daniae et Norvegiae, ducatibus Slesvici et Holsatiae, comitatibus Oldenburgi et Delmenhorstiae, vol. 1-51, Hafniae 1761-1883.

Erndtel C.H., Warsavia Physice Illustrata, Sive De Aere, Aquis, Locis Et Incolis Warsaviae, Eorundemque Moribus Et Morbis Tractatus; Cui Annexum Est Viridarium, Vel Catalogus Plantarum Circa Warsaviam Nascentium, Dresdae 1730.

Flora polska. Rośliny naczyniowe Polski i ziem ościennych, vol. 1, ed. by M. Raciborski, W. Szafer, Kraków 1919; vol. 2, ed. by W. Szafer, Kraków 1921; vol. 3, ed. by W. Szafer, Kraków 1927; vol. 4, ed. by W. Szafer, Kraków 1930; vol. 5, ed. by W. Szafer, Kraków 1935; vol. 6, ed. by W. Szafer, Kraków 1947; vol. 7, ed. by W. Szafer, B. Pawłowski, Kraków - Warszawa 1955; vol. 8, ed. by W. Szafer, B. Pawłowski, Warszawa 1959; vol. 9, ed. by W. Szafer, B. Pawłowski, Kraków 1960; vol. 10, ed. by B. Pawłowski, Warszawa - Kraków 1963; vol. 11, ed. by B. Pawłowski, Warszawa - Kraków 1967; vol. 12, ed. by B. Pawłowski, A. Jasiewicz, Warszawa - Kraków 1971; vol. 13, ed. by 
B. Pawłowski, A. Jasiewicz, Warszawa - Kraków 1972; vol. 14, ed. by A. Jasiewicz, Warszawa - Kraków 1980; vol. 15, ed. by Z. Mirek, Kraków 1995.

Flora SSSR, ed. by V.L. Komarov, vol. 4, Leningrad 1935.

Gilibert J.E., Flora lituanica inchoata, seu enumeratio plantarum quas circa Grodnam collegit et determinavit, vol. 1-2, Vilnae 1781-1782.

Gmelin J.G., Flora Sibirica, sive Historia plantarum Sibiriae, vol. 1-4, Petropoli 17471769.

Jacquin N.J., Florae Austriacae, sive, Plantarum selectarum in Austriae archiducatu sponte crescentium icones, ad vivum coloratae, et descriptionibus, ac synonymis illustratae, vol. 1-5, Viennae 1773-1778.

Joannicy G., Plantarum Cracoviensium indicem proprium Latine confectum, Cracoviae 1616.

Jundziłł S.B., Opisanie roslin litewskich według układu Linneusza, Wilno 1811.

Jundziłł S.B., Opisanie roslin $w$ prowincyi W. X. L. naturalnie rosnących według układu Linneusza przez x. B.S. Jundziłła S.P. w Wilnie 1791, Wilno 1791.

Kluk K., Dykcyonarz roślinny, w którym podług układu Linneusza są opisane rośliny nietylko kraiowe dzikie, pożyteczne, albo szkodliwe, na roli, w ogrodach , oranzeriach, utrzymywane, ale oraz y cudzoziemskie, ktoreby w kraiu pożyteczne byc mogły, albo z ktorych mamy lekarstwa, korzenie, farby, etc. albo ktore jakową nadzwyczaynosc w sobie maia, ich zdatnosci lekarskie, ekonomiczne, dla ludzi, koni, bydła, owiec, pszczot, i t.d. utrzymywanie etc. Z poprzedzaiącym wykładem słow Botanicznych, y kilkorakim na końcu Regestrem, vol. 1-3, Warszawa 1788-1788.

Lamarck J.B., Flore françoise, ou, Description succincte de toutes les plantes qui croissent naturellement en France disposée selon une nouvelle méthode d'analyse, \& à laquelle on a joint la citation de leurs vertus les moins équivoques en médecine, \& de leur utilité dans les arts, vol. 1-3, Paris 1778.

Lietuvos TSR Flora, vol. 6, red. V. Galinis et al., Vilnius 1980.

Linnaeus C., Flora Svecica Exhibens plantas per Regnum Sveciae Crescentes, Lugduni Batavorum 1745.

Loesel J., Flora Prussica, sive Plantae in Regno Prussiae sponte nascentes, Königsberg 1703.

Motty J.B., Leitfaden der Botanik, Posen 1830.

Muralt J., Physicae specialis, pars quarta, botanologia, seu Helvetiae Paradisus, Tiguri 1710.

Ölhafen N., Elenchus plantarum, circa nobile Borussorum Dantiscum, sua sponte nascentium, [Dantisci] 1643.

Ray J., Methodus plantarum emendata et aucta. In quâ notae maxime characteristicae exhibentur, quibus stirpium genera tum summa, tum infima cognoscuntur \& à se mutuo dignoscuntur, non necessariis omissis. Accedit methodus graminum, juncorum et cyperorum specialis, Londini 1703.

Reyger G., Tentamen florae Gedanensis methodo sexuali adcommodatae, vol. 1-2, Dantisci 1764-1766.

Ritschl G., Flora des Grossherzogthums Posen, Berlin 1850.

Schaeffer J.C., Fungorum qui in Bavaria et Palatinatu circa Ratisbonam nascuntur icones, nativis coloribus expressae, vol. 1-4, Ratisbonae 1762-1774. 
Schneeberger A., Catalogus stirpium quarundam Latinè et Polonicè conscriptus, Cracoviae 1557.

Schreber J.C.D.E. von, Beschreibung der Gräser nebst ihren Abbildungen nach der Natur, vol. 1-2, Leipzig 1769-1772.

Szafer W., Kulczyński S., Pawłowski B., Rośliny polskie. Opisy i klucze do oznaczania wszystkich gatunków roślin naczyniowych rosnących w Polsce bądź dziko bądź też zdziczałych lub częściej hodowanych, Lwów - Warszawa 1924.

Thal J., Sylva Hercynia, Sive Catalogus Plantarum Sponte Nascentium In Montibus, Et Locis Vicinis Hercyniae, quae respicit Saxoniam, conscriptus singulari studio, Francofurti ad Moenum 1588.

Waga J., Flora Polska jawno kwiatowych rodzajów czyli Botaniczne opisy tak dzikich jako i hodowanych pod otwartem niebem jawno kwiatowych Królestwa Polskiego Roślin, vol. 1-2, Warszawa 1847-1848.

Wigand J., Vera historia de succino Borussico, de alce Borussia et de herbis in Borussia nascentibus, Jenae 1590.

\section{Critical Literature}

Grębecka W., Badania szaty roślinnej prowadzone w ośrodku wileńskim i krzemienieckim (1781-1840), [in:] Wkład wileńskiego ośrodka naukowego w przyrodnicze poznanie kraju (1781-1842), ed. by J. Babicz, W. Grębecka, Wrocław - Gdańsk 1988 (Monografie z Dziejów Nauki i Techniki, vol. 141), p. 115-225.

Grębecka W., Wilno-Krzemieniec. Botaniczna szkoła naukowa (1781-1841), Warszawa 1998 (Rozprawy z Dziejów Nauki i Techniki, vol. 7).

Historia Nauki polskiej, vol. 2, ed. by S. Suchodolski, Wrocław - Warszawa - Kraków 1970.

Hryniewiecki B., Rozwój botaniki w Polsce. Kraków 1948 (PAU Historia Nauki Polskiej w Monografiach, vol. 8).

Köhler P., Leksykon Botaników Polskich. Dictionary of Polish Botanists. 80. Stanisław Bonifacy Jundzitł, „Wiadomości Botaniczne” vol. 55, 2011, no 1-2, p. 94-98.

Köhler P., Naukowa spuścizna Jeana Emmanuela Giliberta w Polsce (egzemplarze dziet, recepcja), „Kwartalnik Historii Nauki i Techniki” vol. 60, 2015, no 1, p. 185-215.

Kosiek Z., Botanika, [in:] Zarys dziejów nauk przyrodniczych w Polsce, ed. by K. Maślankiewicz, Warszawa 1983, p. 413-479.

Mägdefrau K., Historia botaniki. Życie $i$ dokonania wielkich badaczy, transl. by M. Mularczyk, Wrocław 2004 (Prace Ogrodu Botanicznego Uniwersytetu Wrocławskiego, vol. 7 no. 1).

Rostafiński J., Słownik polskich imion rodzajów oraz wyższych skupień roślin poprzedzony historyczną rozprawą o źródłach, Kraków 1900 (Materyały do Historyi Języka i Dyalektologii Polskiej, vol. 1).

Sławiński W., X. Stanisław Bonifacy Jundziłf profesor Historii Naturalnej Wszechnicy Wileńskiej. The Rev. Stanisław Bonifacy Jundziłt Professor of Natural History in the University of Wilno „Annales Universitatis Mariae Curie-Skłodowska Lublin - Polonia” section E, vol. 1, 1947, Supplementum I.

Zemanek A., Zarys historii botaniki w Polsce, [in:] Dzieje nauki. Nauki ścisłe i przyrodnicze, ed. by R.W. Gryglewski et al., Warszawa - Bielsko-Biała 2011, p. 453-455. 
Prof. Piotr Köhler works in the Institute of Botany of the Jagiellonian University in Kraków. His research interests include history of botany, history of polar studies, and historical ethnobotany.

e-mail: piotr.kohler@uj.edu.pl

Article submitted on 18 March 2020

Article accepted on 10 April 2020

\section{Pierwsza flora Polski}

Flora jest publikacją zawierającą listę gatunków dzikich roślin z danego region wraz z danymi o stanowiskach, informacjami o ich morfologii oraz kluczami do ich oznaczania. Sylva Hercynia Johannesa Thala jest uważana za pierwszą opublikowaną florę. Począwszy od XVIII w. publikowano flory obejmujące całe kraje zachodniej Europy. Opisanie roslin w prowincyi $W$. X. L. naturalnie rosnących według układu Linneusza Stanisława Bonifacego Jundziłła zostało wydane drukiem w 1791 r. Obejmuje 1297 gatunków, w tym 1052 roślin kwitnących, 85 mchów, 64 grzyby, 49 porostów, 34 porosty i 13 glonów, oraz zawiera 97 stanowisk z Korony oraz 198 z Litwy. Gatunki są uporządkowane według systemu Linneusza, a ich opisy są zwięzłe. Wbrew swemu tytułowi Opisanie roslin dotyczy zarówno Litwy, jak i Polski, dlatego powinno być także uznawane za pierwszą polską florę. Opisanie roslin odegrało ważną rolę w dziejach polskiej botaniki, zwłaszcza w rozwoju florystyki w Polsce i na Litwie w początkach XIX w. 